\section{Relação materno-fetal} em camundongos experimentalmente infectados pelo Trypanosoma cruzi

Utilizando como modelos experimentais a infecção de camundongos $\mathrm{C} 3 \mathrm{H} / \mathrm{He}$ ou $\mathrm{BALB} / \mathrm{C}$ com amostras de baixa e média virulência do Trypanosoma cruzi foram determinados alguns pontos da relação materno-fetal na infecção chagásica. Nestes modelos o acasalamento, a fertilização, a evolução da gravidez e o nascimento das crias ocorreram com sucesso. Os resultados mostraram que descendentes de mães chagásicas apresentaram baixa de resistência quando infectados pelo $T$. cruzi às 8 semanas de idade. Esta baixa de resistência foi expressa por maiores níveis de parasitemia e maiores taxas de mortalidade que aquelas observadas nos animais controle. A idade e o sexo mostraram ser fatores importantes neste fenômeno. Estes resultados sugerem que produtos do sistema imune materno podem modular a resposta imune na prole.

Comparamos também os títulos de anticorpos anti-Trypanosoma cruzi de diferentes isotipos (ELISA) presentes no leite e soro de fêmeas $B A L B / c$ infectadas e seus controles, verificando que embora não exista diferença entre a concentração de lgG2b observada no leite de fêmeas chagásicas ou seus controles, esta imunoglobulina é significativamente menos transferida do soro ao leite em fêmeas chagásicas. Animais machos, descendentes de mães chagásicas, com 4 semanas de idade, não infectados, apresentaram título de lgG2b anti- $T$. cruzi inferior ao observado em fêmeas nas mesmas condições, o que não aconteceu no grupo controle. Animais BALB/c machos ou fêmeas, descendentes de mães chagásicas, infectados às 8 semanas de idade, apresentaram menor produção de IgG2b anti-T. cruzique seus controles. Estes achados são interessantes porque é clássico na literatura a maior suscetibilidade de camundongos machos à infecção pelo $T$. cruzi e que os anticorpos responsáveis pela proteção contra este parasito estão incluídos na subclasse IgG2b.

\section{Feto-maternal relationship in experimental Trypanosoma cruzi- infected mice}

This study reports some aspects of fetomaternal relationship in Chagas' disease using as model experimental infection of $\mathrm{C} 3 \mathrm{H} / \mathrm{He}$ or $\mathrm{BALB} / \mathrm{c}$ mice with low and medium virulent Trypanosoma cruzi samples. In these models mating, fertilization, pregnancy evolution and delivery were carried out successfully. The results showed that the offspring born to chagasic mothers present decreased resistance to acquired T. cruzi infection at eight weeks of age. This decreased resistance was expressed by higher levels of parasitaemia and higher mortality as compared to controls. Age and sex were shown to be important factors of this phenomenon. The data suggest that maternal immune system products can modulate the immune response of the offspring.

We also compared anti- $T$. cruzi antibodies from different isotype (ELISA) in milk and serum from $B A L B / c$ infected female and their controls and although chagasic and control female displayed no difference in milk IgG2b concentration, this immunoglobulin is less transferred from serum to milk in chagasic females. Four week non-infected male mice born to chagasic mothers displayed lower anti- $T$. cruzi IgG2b titres than that observed in females. This result was not observed in the control group. Male and female $\mathrm{BALB} / \mathrm{c}$ mice born to chagasic mothers infected at 8 weeks after birth displayed lower anti- $T$. cruzi IgG2b antibodies production than control group. These are interesting findings because it is well known that male mice are more suscetible to $T$. cruzi infection than female and that IgG2 antibodies, specially subclass IgG2b, are involved in the protection against $T$. cruzi infection.

We also evaluate the involvement of tumor necrosis factor alpha (TNF- $\alpha$ ) in feto-maternal relationship in T. cruzi infection. Chronically infected pregnant $B A L B / C$ mice displayed significantly higher levels of circulating TNF- $\alpha$ than both only infected and only pregnant 
Nós estudamos também o envolvimento do fator de necrose tumoral alfa (TNF- $\alpha$ ) na relação materno-fetal na infecção pelo $T$. cruzi. Fêmeas BALB/c grávidas infectadas cronicamente apresentaram níveis de TNF- $\alpha$ circulante significativamente mais elevados que fêmeas somente infectadas ou somente grávidas. Não detectamos TNF- $\alpha$ no soro de fêmeas grávidas não infectadas. Fetos obtidos de fêmeas infetadas apresentaram significativamente mais células tímicas contendo mRNA para TNF- $\alpha$ que fetos obtidos de mães não infectadas. Os descendentes de mães infectadas e seus controles, infectados dois meses após o nascimento, apresentaram quantidades similares de TNF- $\alpha$ circulante durante uma infecção crônica. A injeção intravenosa de lipopolissacáride aumenta a produção de TNF- $\alpha$ em proles descendentes de mães infectadas a níveis mais altos que aqueles observados em seus controles. Estes resultados sugerem que fetos e descendentes de mães infectadas são preparados para produzir níveis elevados de TNF- $\alpha$.

Finalmente estudamos o papel dos anticorpos no efeito prejudicial que a infecção materna exerce sobre a prole infectada posteriormente. O estudo foi feito injetando soro obtido de fêmeas grávidas cronicamente infectadas ou anticorpos anti-T. cruzi purificados em fêmeas não infectadas em período gestacional e de lactação. Foi observado que os anticorpos injetados são transferidos para a prole tanto em período gestacional como de lactação. Quando as proles foram infectadas dois meses após o nascimento, descendentes de mães tratadas com soro de animais cronicamente infectados ou com anticorpos purificados apresentaram parasitemias significativamente mais elevadas que descendentes de mães que receberam soro controle ou imunoglobulina não relacionada ao T. cruzi. Estes resultados indicam que anticorpos anti-T. cruzi e/ou fatores solúveis contidos no soro de animais infectados, quando tranferidos da mãe para seus filhotes, são capazes de agravar uma infecção pelo T. cruzi na prole. animals. TNF- $\alpha$ was undetectable in sera of uninfected and nonpregnant mice. Fetuses from infected mice exhibited significantly more cells containing TNF- $\alpha$ mRNA in their thymus than fetuses from uninfected mothers. When infected two month after birth, offspring born to infected and uninfected mothers displayed similar amounts of circulating TNF- $\alpha$ during chronic infection. An intravenous injection of lipopolysaccharide during acute infection strongly increased the production of TNF- $\alpha$ in offspring born to infected mothers to levels higher than those in progeny from uninfected mice. These results suggest that fetuses and offspring of infected mothers are primed to produce elevated levels of TNF- $\alpha$.

Finally, we studied the role of antibodies in the previously harmful effect of $T$. cruzi-infected mothers on progeny infection. It was studied by injecting either serum from chronically infected animals or purified $T$. cruzi-specific antibodies into uninfected mice during gestation and lactation periods. It was verified that injected antibodies were transferred to offspring both in gestational and lactation period. When infected eight weeks after birth, the offspring treated with chronic serum or purified antibodies displayed significantly higher parasitaemia than offspring from mothers receiving control serum or T. cruzi unrelated immunoglobulins. These results indicate that $T$. cruzi reactive antibodies and/or soluble factors contained in sera of infected mice, when transferred from mothers to their young, are able to worsen $T$. cruzi acquired infection in the offspring.

\section{Silvana Marques de Araújo}

Tese apresentada ao Instituto de Ciências Biológicas

da Universidade Federal de Minas Gerais

para obtenção do Título de Doutor.

Belo Horizonte, MG, Brasil, 1994. 